\title{
Identification of a seasonal pattern to brain metastases
}

\author{
This article was published in the following Dove Press journal: \\ Neuropsychiatric Disease and Treatment \\ 7 March 2016 \\ Number of times this article has been viewed
}

\author{
Minas Sakellakis' \\ Angelos Koutras' \\ Maria Pittaka ${ }^{2}$ \\ Dimitrios Kardamakis ${ }^{2}$ \\ Melpomeni Kalofonou' \\ Haralabos P Kalofonos' \\ Despina Spyropoulou ${ }^{2}$ \\ 'Division of Oncology, Department \\ of Medicine, ${ }^{2}$ Department of Radiation \\ Oncology, University Hospital, Patras \\ Medical School, Rion, Patras, Greece
}

Correspondence: Minas Sakellakis

Division of Oncology, Department of

Medicine, University Hospital, Patras

Medical School, Rion 26504, Patras,

Greece

Tel +3026I0999535

Fax +302610994645

Email doctorsakellakis@yahoo.com

\section{Dear editor}

We have previously tested our hypothesis that there is a seasonality in the incidence of carcinomatous meningitis. ${ }^{1}$ Although further validation is needed in a larger cohort, we found that leptomeningeal metastasis occurred more often during warm months of the year which, in the case of Greece, is the period generally marked with the larger daytime length. ${ }^{1}$ Carcinomatous meningitis is closely related to brain metastasis, and a logical question is whether warm season is marked by a greater propensity also for

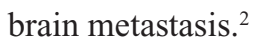

We conducted a single-center retrospective review of the medical records of patients with brain metastases that received whole brain irradiation from 2008 to 2013 (6 years).

We extracted the following parameters for each patient: sex, age, tumor histology, date of first cancer diagnosis, and date of brain metastasis diagnosis. We divided the year into two parts based on the official meteorological data regarding seasonal temperature distribution in our region (15 April-15 October and 15 October-15 April). ${ }^{3}$ Each patient was categorized in either the first or second group, depending on the date of first diagnosis of brain metastasis. Whenever we could not clearly specify whether a patient developed brain metastases during either the first or the second period, the patient was excluded. Statistical analysis was performed using binomial testing.

A total of 343 patients with brain metastases were eligible for our study. Median age was 63 years. Overall, 142 patients developed brain metastases during the cold period, while 199 patients developed metastases during the warm period (142 vs 199, $P=0.002)$. Seasonality was noted mostly among non-newly diagnosed cancer patients $(P=0.002)$. Regarding tumor histology, seasonality was mostly evident in colorectal cancer $(P=0.013)$, renal cell $(P=0.04)$, and small-cell lung cancer $(P=0.04)$.

Our results provide strong evidence that there might be a seasonal variability in the incidence of brain metastases, with a predilection toward the warm months of the year. This finding should be considered hypothesis-generating.

Interestingly, non-small-cell lung cancer, which was the most frequently diagnosed neoplasia in our study ( $\mathrm{n}=143)$, was not associated with such a periodicity $(P=0.518)$. On the other hand, small-cell lung cancer, renal cell, and colorectal cancer were associated with a significant seasonal difference, but the results should be interpreted with caution due to the small number of patients in each of these subgroups.

Thus far, no studies have been widely published or reported (including our institution) on the observation of higher cancer diagnosis during warm months. ${ }^{4}$ What is 
important to note is that despite seasonal temperature fluctuations, our region is not isolated and our hospital is easily accessible during any time of the year.

Temperature fluctuations pose various physiologic responses in an individual that can be directly or indirectly related to cancer. ${ }^{5}$ Moreover, seasonal temperature fluctuations are related to the propensity of humans toward various infective agents, thus posing different immunologic responses throughout the year. ${ }^{6}$ This may influence the course of immunity-related diseases, such as cancer.

\section{Ethics}

This study was approved by the University of Patra Research Ethics Committee. Patient consent was deemed exempt by the University of Patra Research Ethics Committee as the study was retrospective and most of the patients were not alive at the time the study.

\section{Acknowledgment}

This letter did not receive funding from any organization.

\section{Disclosure}

All authors declare no conflicts of interest in this communication.

\section{References}

1. Koutras A, Sakellakis M, Makatsoris T, et al. Seasonal variability in the incidence of carcinomatous meningitis. J Neurosurg. 2015;9:1-4.

2. Balm M, Hammack J. Leptomeningeal carcinomatosis: presenting features and prognostic factors. Arch Neurol. 1996;53:626-632.

3. Hellenic National Meteorological Service. Patra. Available from: http://www.hnms.gr/hnms/english/climatology/climatology_region_ diagrams_html?dr_city=Patra. Accessed January 8, 2016.

4. Moan J, Lagunova Z, Bruland O, Juzeniene A. Seasonal variations of cancer incidence and prognosis. Dermatoendocrinol. 2010;2(2):55-57.

5. Tromp SW. Medical Biometeorology. New York: Elsevier; 1963.

6. Tang JW. The effect of environmental parameters on the survival of airborne infectious agents. J R Soc Interface. 2009;(6 Suppl):S737-S746.

Dove Medical Press encourages responsible, free and frank academic debate. The content of the Neuropsychiatric Disease and Treatment 'letters to the editor' section does not necessarily represent the views of Dove Medical Press, its officers, agents, employees, related entities or the Neuropsychiatric Disease and Treatment editors. While all reasonable steps have been taken to confirm the content of each letter, Dove Medical Press accepts no liability in respect of the content of any letter, nor is it responsible for the content and accuracy of any letter to the editor.

\section{Publish your work in this journal}

Neuropsychiatric Disease and Treatment is an international, peerreviewed journal of clinical therapeutics and pharmacology focusing on concise rapid reporting of clinical or pre-clinical studies on a range of neuropsychiatric and neurological disorders. This journal is indexed on PubMed Central, the 'PsycINFO' database and CAS, and is the official journal of The International Neuropsychiatric Association (INA). The manuscript management system is completely online and includes a very quick and fair peer-review system, which is all easy to use. Visit http://www.dovepress.com/testimonials.php to read real quotes from published authors. 